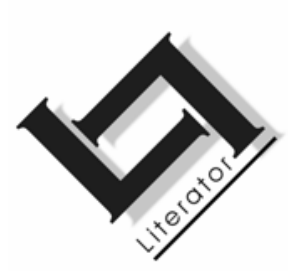

\title{
Die hiërargiese ontwikkeling en grammatiese kenmerke van die Noord- Sotho werkwoordstam -ba
}

\author{
W.J. Pretorius \\ Departement Afrikatale \\ Universiteit van Johannesburg \\ JOHANNESBURG \\ E pos: navorsing@voortrekkermon.org.za
}

\begin{abstract}
The hierarchical development and grammatical features of the Northern Sotho verb stem -ba

The objective of this article is to describe the synchronic grammatical features of the Northern Sotho verb stem -ba as well as to indicate the diachronic developmental process of this language form. A lack of sufficient knowledge in this regard exists due to the fact that very little information can be obtained from any publication or research project. The focus of this article is particularly on the structural and semantic characteristics of -ba when functioning as an auxiliary verb stem in word group context. The cognitive meaning as well as various delicate shades of meaning, which are generated as translation possibilities in different contexts, is investigated. Reference is also made to tense and aspect that are respectively determined by the auxiliary and complementary verbs per se. Categorial and hierarchical rank shifting is also illustrated by means of suitable examples.

Data and examples are mainly obtained from the study of Pretorius (2004). These examples have been recorded after some sound ground-work has been undertaken. Various examples of auxiliary verb groups have not only been recorded from the literature, but also from daily conversations. It should, however, be made clear that no direct quotations from the literature have been made - only structures from the examples have been selected and processed before being submitted for verification.
\end{abstract}


The data of selected examples have been submitted to three Northern Sotho first language speakers. These people are well equipped in both the practical as well as theoretical knowledge of Northern Sotho. The people concerned are Mr. S.M. Mabule (Vista), Mr. R.J. Mampuru (Vista), and Mr. S.J. Motshegoa (Institute for African Languages). These gentlemen are also fluent in Afrikaans which they all studied at tertiary level.

\section{Opsomming}

\section{Die hiërargiese ontwikkeling en grammatiese kenmerke van die Noord-Sotho werkwoordstam -ba}

Die doel van hierdie artikel is om die sinchroniese grammatiese kenmerke van die Noord-Sotho werkwoordstam -ba te beskryf, asook om die diachroniese ontwikkelingsgang van die taalvorm aan te toon. Daar bestaan tans 'n leemte in dié verband, aangesien beperkte kennis oor hierdie aspek in publikasies en navorsingsprojekte aangetref is. Die fokus van hierdie artikel val veral op die strukturele en semantiese kenmerke van -ba as hulpwerkwoordstam in woordgroepkonteks. Die grondliggende betekenis, asook verskeie betekenisnuanses wat as vertalingsmoontlikhede in verskeie kontekste gegenereer word, word ondersoek. Daar word ook na tyd en aspek verwys wat respektiewelik deur die hulp- en komplementêre werkwoorde bepaal word. Kategoriale en hiërargiese rangverskuiwing word ook met behulp van toepaslike voorbeelde aangetoon.

Data en voorbeelde is hoofsaaklik verkry uit die studie van Pretorius (2004). Sodanige voorbeelde in die studie is opgeteken nadat belangrike grondwerk gedoen is. Verskeie voorbeelde van hulpwerkwoordgroepe is nie slegs in die literatuur opgeteken nie, maar ook in alledaagse gesprekvoering. Daar word egter daarop gewys dat geen direkte aanhalings uit die literatuur van spesifieke voorbeelde geneem is nie, maar dat slegs strukture uit die bronne opgeteken is wat later in taalkonteks aangepas en verwerk is en vir kontrolering voorgelê is.

Die data van die geselekteerde voorbeelde is aan drie NoordSotho-moedertaalsprekers voorgelê. Hierdie persone beskik oor besondere praktiese vaardighede in hulle taal, asook 'n sterk teoretiese onderbou, aangesien hulle akademiese kwalifikasies in Noord-Sotho taalkunde en letterkunde verwerf het. Die voorbeelde is aan mnr. S.M. Mabule (Vista), mnr. R.J. Mampuru (Vista) en mnr. S.J. Motshegoa (Instituut vir Afrikatale) voorgelê vir kontrolering en kommentaar. Genoemde persone het ook besondere praktiese vaardighede in Afrikaans. Hulle het Afrikaans as vak op tersiêre vlak bestudeer. 


\section{Inleiding}

Deur die jare het verskeie Noord-Sotho-grammatici die werkwoordstam -ba verskillend beskryf en dikwels foutiewelik as 'n bepaalde taalvorm geklassifiseer. So byvoorbeeld klassifiseer Ziervogel et al. (1969:102-107) die kopulatiewe werkwoordstam -ba as 'n hulpwerkwoordstam in 'n konteks soos go ba monna (om 'n man te word/wees). Hierdie foutiewe klassifisering van -ba is gedoen op grond van sy vertalingsekwivalent in Afrikaans, naamlik "wees" of "word". Posthumus (2000:347) wys ook op die uiteenlopende - maar in die meeste gevalle foutiewe - interpretasies van dié taalvorm in Zulu.

Navorsing in bogenoemde verband dui daarop dat -ba in taalkonteks sinchronies die volgende grammatiese kenmerke vertoon, naamlik:

- kopulatiewe werkwoordstam;

- hulpwerkwoordstam; en

- komponent van 'n monomorfematiese voegwoord.

Die kopulatiewe stam -ba is al redelik omvattend deur navorsers soos Van Wyk (1953), Posthumus (1978) en Taljard (1999) ondersoek en grammaties beskryf. Kotzé (1993:16-28) se navorsing oor die kopulatiewe werkwoordstam -ba in Hanamwa lewer ook 'n besondere bydra rakende die kopulatiewe aard van die stam, waarvan verskeie verskille met die Noord-Sotho-ekwivalent -ba aangetoon word. Betreffende -ba se status as hulpwerkwoordstam bestaan daar egter geen noemenswaardige navorsing tot op hede nie. Veral die besondere semantiese kenmerke wat dié stam in hulpwerkwoordgroepverband openbaar, is nog 'n braak veld vir die toekomstige navorser om te ontgin. Van Staden (1988) het wel waardevolle navorsing gedoen oor die hiërargiese ontwikkelingsproses van -ba vanaf werkwoordstam na voegwoord - maar ook ten opsigte van dié aspek bestaan daar 'n behoefte aan indringende navorsing.

Die grammatikale status van die taalvorm -ba soos dit hierbo aangetoon is, is hoofsaaklik die gevolg van 'n diachroniese ontwikkelingsproses. Hierdie proses word hieronder deur middel van voorbeelde en illustrasies in taalkonteks bespreek. 


\section{2. -Ba as kopulatiewe werkwoordstam}

\subsection{Fundamentele grammatiese klassifisering}

Lanham (Taljard, 1999:291) beweer dat die werkwoordstam -ba voorheen 'n nie-kopulatiewe werkwoordstam was met die oorspronklike betekenis van "coming into existence". Die kopulatiewe werkwoordstam wat later uit hierdie werkwoordstam ontwikkel het, word ook sinchronies met 'n dinamiese betekenis geassosieer.

Binne Halliday (1961) se grammatiese teoretiese skema kan die kopulatiewe werkwoord met -ba soos volg diagrammaties geklassifiseer word:

1.

Go ba

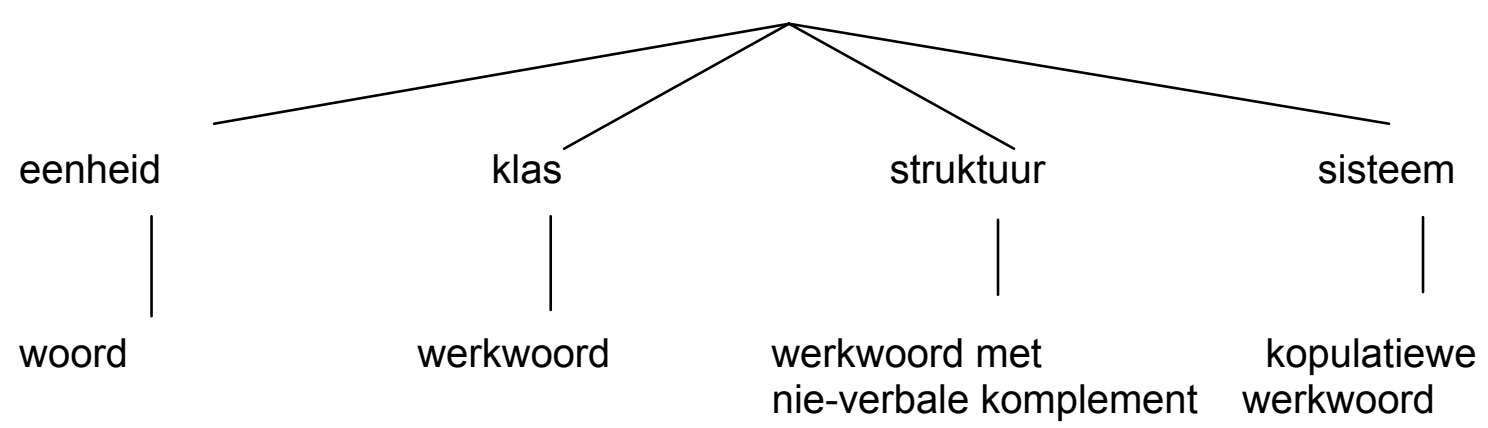

Vanweë sy "normale" morfologiese kenmerke word -ba, volgens Taljard (1999:291), nie as 'n defektiewe werkwoordstam beskou nie.

\subsection{Morfologiese en sintaktiese kenmerke}

- $B a$ as 'n kopulatiewe werkwoordstam het die morfologiese struktuur van wortel (-b-) en uitgang (-a). Soos hierbo vermeld, is die aard en wese van dié stam reeds deur Van Wyk (1953:48-62) vir NoordSotho in oënskou geneem, asook deur Posthumus (1978:105-112) vir Zulu. Uit hierdie navorsing blyk dit duidelik dat die kopulatiewe werkwoord met die stam -ba in 'n enkelvoudige predikaat kan optree wat 'n inchoatiewe (d.i. dinamiese of wordende) betekenis genereer. Die stam -ba vertoon ook wisselvorme wat in bepaalde kontekste voorkom, soos -bile, -be, -bê en -eba. Die onveranderlike onderwerpsmorfeem word volgens Taljard (1999:295) geselekteer in gevalle waar 'n identifiserende relasie (tussen onderwerp en komplement) uitgedruk word. Soos blyk uit die voorbeelde hieronder, selekteer die kopulatiewe werkwoord 'n nie-verbale komplement: 
1. Bana e ba barutiši.

(Die kinders word onderwysers.)

2. Bana e bile bašomi.

(Die kinders het werkers geword.)

3. Bana ga e be barutiši.

(Die kinders word nie onderwysers nie.)

4. Bana e be barutiši.

(Die kinders moet onderwysers word.)

5. Ebang barutiši!

(Julle moet onderwysers word!)

Die kopulatiewe werkwoord met die stam -ba kan ook sintakties deel vorm van 'n komplement en in 'n hulpwerkwoordgroep funksioneer, byvoorbeeld:

6. Mantšu a gagwe nka be a bile a ba selepe se bogale.

(Sy woorde sou 'n skerp byl gewees het.)

\subsection{Semantiese kenmerke}

Die kopulatiewe werkwoordstam -ba word gebruik om die volgende semantiese relasies tussen die onderwerp en die komplement te merk.

7. Identifisering (Inchoatief):

Bašemane e ba badiši.

(Die seuns word wagters.)

8. Assosiasie (Inchoatief):

Bašemane ba tlo ba le morutiši.

(Die seuns sal saam met 'n onderwyser wees.)

9. Besitting (Inchoatief):

Bašemane ba tlo ba le dithipa. 
(Die seuns sal messe hê.)

10. Lokaliteit (Inchoatief):

Bašemane ba tlo ba sekolong.

(Die seuns sal by die skool wees.)

11. Kwaliteit (Inchoatief):

Bašemane ba tlo ba botho.

(Die seuns sal vriendelik word.)

Van Wyk (1953:48-49) het in daardie stadium die kopulatiewe werkwoordstam -ba beskryf as 'n stam wat 'n imperfekte kopula uitdruk - 'n term wat hy van Endemann (1911) in sy "Wörterbuch" ontleen het, naamlik imperfekte sein. Afhangende van die gebruikskonteks moet dié werkwoordstam volgens hom in Afrikaans met "wees" of "word" vertaal word. Die "imperfekte" kopulatief kan volgens Van Wyk ook gebruik word om "gewoontelike handeling of toestand" te impliseer, byvoorbeeld:

12. Batho ba be le dikgomo.

(Die mense het gewoonlik beeste.)

Dit impliseer dat die mense in dié geval beeste kry of dat hulle gewoonlik beeste het.

Die "imperfekte sein" waarna Endemann hierbo verwys, word gebaseer op die feit dat die werkwoord die kenmerk van aspek oordra, wat Louwrens (1994:123) onderskei met die term "hipotetiese imperfektiwiteit". Die handeling of proses in dié geval word gekoppel aan 'n bepaalde tydsveranderingspunt in die toekoms, waartydens die handeling of proses onvoltooid is.

Posthumus (1978:105-110) gebruik die term "inchoatief" om na sekere kopulatiewe met die stam -ba te verwys wat in Zulu voorkom. Hy wys ook op die dualiteit van -ba, aangesien dit aanduidend van sowel inchoatiwiteit (word), as nie-inchoatiwiteit (wees) kan wees, afhangende van die komplement in kopulatiewe woordgroepverband, byvoorbeeld:

13. Bana ba ba gona. 
(Die kinders is besig om teenwoordig te wees.) (Nieinchoatiwiteit)

14. Bana e tlo ba barutiši.

(Die kinders sal onderwysers word.) (Inchoatiwiteit)

Posthumus se onderskeiding van "inchoatiwiteit" hang nóú saam met die aspektuele onderskeiding van "hipotetiese imperfektiwiteit" waarna Louwrens (1994:125) verwys. Louwrens gebruik egter die term, soos hierbo aangevoer word, om na 'n spesifieke toekomende tydsvorm te verwys, terwyl Posthumus se term op 'n wordende proses dui wat ook 'n tydsverwysingspunt in die toekoms kan impliseer wat onvoltooid is.

\section{3. -Ba as hulpwerkwoordstam}

Dit word algemeen aanvaar dat hulpwerkwoorde in Noord-Sotho histories uit basiese werkwoorde ontwikkel het (vgl. Louwrens, 1991:50 in dié verband). In die taalontwikkelingsproses het die kopulatiewe werkwoord met -ba ook gedien as basis (korrelaat) waaruit bepaalde hulpwerkwoorde ontwikkel het. In dié proses het 'n bepaalde sisteemverandering ingetree, in die sin dat die kopulatiewe werkwoord in hulpwerkwoordkonteks bepaalde grammatiese veranderinge ondergaan het.

Ten spyte van oorkoepelende raakpunte het inchoatiwiteit en nieinchoatiwiteit niks met tyd of aspek te doen nie, maar is 'n verdere hoofdelike kategorie naas die bogenoemde twee kategorieë. Aspek het tipies te doen met die interne konstituering van 'n proses of handeling. Die kategorie inchoatief (dinamies/wordend) teenoor nieinchoatief (staties) is 'n noodsaaklike kategorie van alle kopulatiewe. Hierdie kategorieë staan in binêre opposisie teenoor mekaar en die term implikasie word soms as sambreelterm vir hierdie onderskeidinge gebruik. Tipiese voorbeelde is dus progressiwiteit, perfektiwiteit en imperfektiwiteit.

In die ontwikkelingsproses van kopulatiewe werkwoord na hulpwerkwoord het daar, ten opsigte van die kopulatiewe werkwoord, semanties 'n merkbare verskuiwing plaasgevind. Die werkwoord het sy basiese betekenis van inchoatiwiteit verloor en semanties onderskikkend in 'n bepaalde grammatiese verhouding met 'n komplementêre werkwoord in 'n groter betekenisgeheel begin optree. 
Struktureel het daar ook 'n bepaalde verandering ingetree in dié opsig dat die hulpwerkwoord met -ba nie meer, soos in die geval van die kopula as enkelvoudige predikaat, funksioneer nie, maar saam met die hoofwerkwoord in 'n sekere volgorde deel vorm van 'n saamgestelde predikaat.

\subsection{Die hulpwerkwoordstam -ba as tydsmarkeerder}

Aanvanklik het vroeëre grammatici hulpwerkwoorde met die stam -ba as tydsmarkeerders (tense makers) geïnterpreteer. Beyer (1920:26) verwys na gevalle waar die hulpwerkwoord met -ba saam met -tla (toekomende vorm) optree en 'n hoofwerkwoord in die situatief verlede tyd voorafgaan, as die "future perfect tense" van Noord-Sotho, soos dit byvoorbeeld in die volgende voorbeelde hieronder blyk te wees. Die hulpwerkwoorde, soos deurgaans in die artikel, word met 'n onderbroke lyn (---) aangedui, terwyl die komplementêre werkwoord met 'n ononderbroke lyn (_) onderstreep word:

15. Ke tla ba ke šomile.

(Ek sou gewerk het.)

16. Ngwana o tla ba a ithutile go bala.

(Die kind sou geleer het om te lees.)

17. Tau e tla ba e tšhabile.

(Die leeu sou gevlug het.)

Endemann (1966:50) interpreteer voorbeelde, soos 15-17 hierbo, asof die hulpwerkwoord die tyd (tense) bepaal, terwyl die komplementêre werkwoord die voltooidheid of onvoltooidheid (aspek) van die aksie of proses aandui.

Endemann (1876: par. 136) het langer as 'n eeu gelede werkwoordgroepe met die hulpwerkwoordstamme -na en -ba wat in die konsekutief voorkom, beskryf as 'n emfatiese imperfektum-tyd (tense), byvoorbeeld:

18. Ka na ka ba ka dira modiro.

(Ten einde het ek die werk gedoen.) 
By nadere ondersoek blyk dit egter dat die voorbeeld wat Endemann hierbo gee, in die taalontwikkelingsproses in onbruik geraak het. Die hulpwerkwoorde met -na en -ba in die konsekutief tree in moderne standaardtaal uitsluitend ten opsigte van mekaar in die konsekutief op, byvoorbeeld:

19. Ka na ka dira mošomo.

(Ek het ten einde die werk gedoen.)

Teenoor

20. Ka ba ka dira mošomo.

(Ek het uiteindelik die werk gedoen.)

\subsection{Diachroniese kategoriale verskuiwing}

In die ontwikkelingsproses het hulpwerkwoorde met -ba, na analogie van kopulatiewe werkwoorde met -ba soos dié wat in voorbeeld 2133 voorkom, ook sogenaamde klaslose of onveranderlike onderwerpsmorfeme begin neem. Hierdie sisteem- en struktuurverandering word deur die volgende voorbeelde geïllustreer:

21. E ka ba batho.

(Dit kan moontlik mense wees.)

22. E ba bošego.

(Dit word donker.)

23. Batho ya ba balemi.

(Toe was die mense landbouers.)

In voorbeelde 21-23 het -ba die grammatikale status van 'n kopulatiewe werkwoordstam, wat met 'n nie-verbale komplement in 'n kopulatiewe woordgroep kombineer en as enkelvoudige predikaat optree. In die volgende voorbeelde word 'n duidelike kategoriale verskuiwing van die kopulatiewe werkwoorde na hulpwerkwoorde waargeneem:

24. Eka ba ba rekišitše dipudi.

(Dit kan moontlik wees dat hulle die bokke verkoop het.) 
25. E ka ba ba šomile serapeng.

(Dit is moontlik dat hulle in die tuin gewerk het.)

26. Ya ba ba a tloga.

(Dit is toe dat hulle gaan.)

-Ba as hulpwerkwoordstam kan uit die aard van die saak ook 'n veranderlike onderwerpsmorfeem neem. In voorbeelde 24-26 tree die stam met ' $n$ onveranderlike onderwerpsmorfeem op, wat daarop dui dat daar 'n diachroniese verband tussen die kopulatiewe werkwoordstam -ba en die hulpwerkwoordstam -ba bestaan.

In voorbeelde 24-26 het die nie-verbale komplemente van die kopulatiewe woordgroepe weggeval en het die kopulatiewe werkwoorde met -ba in 'n sekere mate hulle kopulatiewe funksie van inchoatiwiteit en nie-inchoatiwiteit verloor. Die kopulatiewe werkwoorde het 'n bepaalde kategoriale verskuiwing ondergaan in die rigting van hulpwerkwoorde, wat semanties en fonologies in 'n bepaalde verhouding met komplementêre werkwoorde in 'n woordgroepverband staan en deel vorm van 'n saamgestelde predikaat. Soos alle ander hulpwerkwoorde tree die hulpwerkwoord met -ba semanties ondersteunend tot komplementêre werkwoorde in woordgroepverband op. Verskeie betekenisnuanses kan in dié geval onderskei word.

\subsection{Betekenisnuanses}

Oor die interpretasie van betekenis ten opsigte van hulpwerkwoordgroepe moet 'n onderskeid getref word tussen 'n kognitiewe of grondliggende betekenis en 'n emosionele subjektiewe interpretasie, wat as vertalingsmoontlikhede aangewend word. In die geval van die hulpwerkwoord met die stam -ba sou daar in die meeste gevalle ' $n$ grondliggende betekenis van in die proses wees blootgelê kon word. Vertalingsekwivalente word gewoonlik deur die gebruik van bepaalde adjunkte gekenmerk.

Die hulpwerkwoord met - $b a$ genereer 'n hele spektrum van betekenisnuanses, wat deur Ponelis (1991:312-315) as verbindingsadjunkte geïdentifiseer word. Betekenisnuanses in dié konteks word grootliks bepaal deur die modus waarin sowel die hulp- as komplementêre werkwoord in woordgroepkonteks voorkom.

'n Bevredigende vertaling van hierdie hulpwerkwoordgroep in sekere kontekste is nie altyd moontlik nie. ' $n$ Element van kopulatiewe aard 
van die korrelaatwerkwoord vind wel neerslag in hulpwerkwoordkonteks, aangesien die inchoatiewe betekenis van "in die proses wees" in die meeste gevalle onderliggend afgelei kan word. Voorbeelde van die ontwikkelingsproses van kopulatiewe werkwoord tot hulpwerkwoord word in die volgende paragrawe toegelig.

\section{Hulpwerkwoordelike vorm}

\subsection{Deonties}

Die begrippe deonties en epistemies wat semantiese kategorieë is waarop modaliteit berus, word hier om pragmatiese redes slegs gebruik om semanties tussen bepaalde hulpwerkwoordgroepe te onderskei.

Hulpwerkwoordgroepe in dié konteks kan om die volgende redes as 'n eerste fase van kategorieverskuiwing beskou word, naamlik:

- Die werkwoord selekteer 'n ander werkwoord as komplement, in plaas van 'n nie-verbale komplement, soos in die geval van die voorbeelde 24-26 hierbo.

- In dié konteks verloor die werkwoord nie heeltemal die inchoatiewe betekenis wat kenmerkend van die korrelaatwerkwoord is nie;

- Die hulpwerkwoordelike vorm funksioneer semanties onderskikkend ten opsigte van die komplementêre werkwoord.

- In dié konteks verskil die hulpwerkwoord tonologies van die korrelaatwerkwoord.

In die volgende voorbeelde word geïllustreer hoedat die hulpwerkwoord nog kenmerkende semantiese en vormlike kenmerke van die korrelaat kopulatiewe werkwoord, wat in die imperatiewe modus voorkom, vertoon:

27. O se ke wa ntetela é bà o sepela.

(Moenie vir my wag nie, wees intussen/solank aan die loop.)

28. O se ke wa ba letela, é bà o etla.

(Moenie vir hulle wag nie, hou intussen aan om te kom.)

29. Ke se ke ka go bolelela lefela é bè o bolela nnete monna! 
(Ek sal nie vir jou sommer net voorsê nie, laat dit wees dat jy die waarheid praat, meneer!)

30. É bà le a ja!

(Laat dit tog wees dat julle eet!)

Die kopulatiewe werkwoord soos in voorbeeld (5) geïllustreer word, neem egter 'n nie-verbale komplement en die e, soos in eba, in daardie konteks is slegs 'n stabiliseerder en het geen semantiese waarde nie. Die hulpwerkwoord in voorbeelde 27-30 word gekenmerk deur 'n onveranderlike onderwerpsmorfeem en dit tree op met 'n werkwoord as komplement. Verder genereer die hulpwerkwoord in hierdie woordgroepkonteks 'n addisionele adverbiale betekenis van intussen/solank soos in die voorbeelde geillustreer word. Tonologies verskil die stabiliseerder en die onderwerpsmorfeem, asook die hulpwerkwoordstam en die kopulatiewe werkwoordstam. Die hulpwerkwoord in voorbeelde 2730 het 'n HL-toonpatroon.

Vergelyk kopulatief:

31. Ėbá monna. (Word 'n man.)

Dit blyk na aanleiding van die voorbeelde hierbo dat -ba in dié konteks onderliggend ' $n$ inchoatiewe betekenis genereer, wat tot gevolg het dat dié hoofhandeling van die aangesprokene wat in die komplementêre werkwoord vervat is, 'n proses in wording impliseer. Louwrens (1994:123) onderskei ten opsigte van dié voorbeelde 'n aspektuele kenmerk van hipotetiese imperfektiwiteit, indien 'n toekomstige proses of handeling geïmpliseer word.

Voorbeelde (28) en (30) word hieronder skematies uiteengesit om onder meer aan te toon dat die hulpwerkwoord in dié konteks bepalend vryer is. Die hulpwerkwoord is vryer in die sin dat die komplementêre werkwoord in meer as een modus kan fungeer, en dat die funksionering van die komplementêre werkwoord in die situatief óf indikatief deur semantiese oorwegings bepaal word. 
2.

(O se ke wa ba letela) e ba o etla!

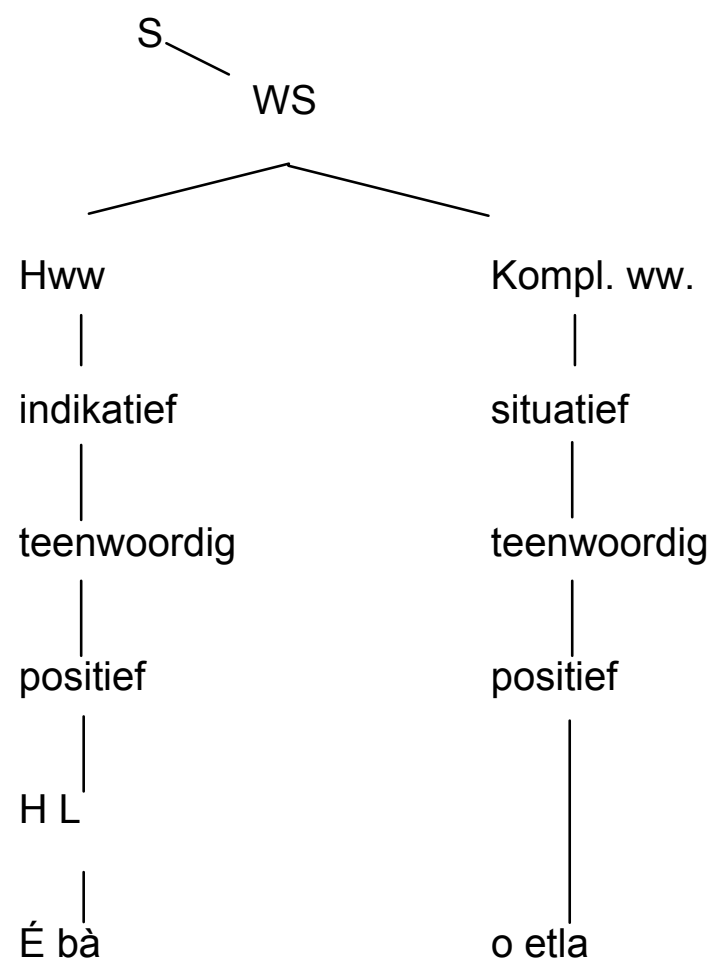

3.

É bà le a ja!

S WS
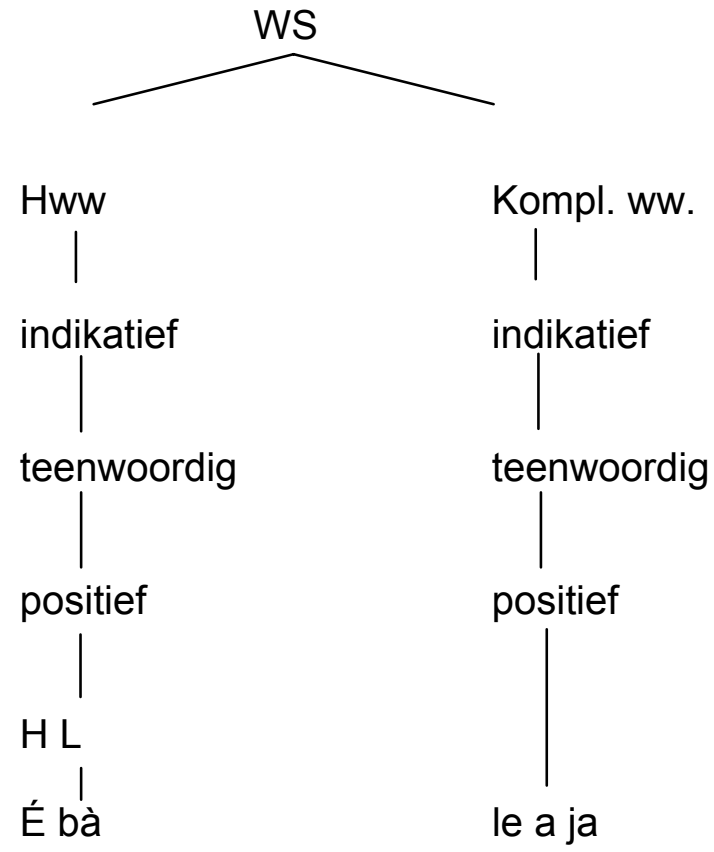


\subsection{Epistemies}

Verskeie betekenisnuanses as vertalingsekwivalente word deur die hulpwerkwoordgroep in dié konteks uitgedruk. Slegs enkele prominente voorbeelde word vervolgens kortliks uitgelig. Die feit dat die komponente van die hulpwerkwoordgroep onder 'n semantiese hoofdelike indeling morfologies beskryf word, impliseer nie dat daar 'n een-tot-een-korrelasie tussen bepaalde morfologiese kenmerke en semantiese implikasie gelê word nie. Trouens, hulpwerkwoordgroepe wat ten opsigte van hulp- en komplementêre werkwoord "morfologies" verskil, kan ooreenstemmende semantiese implikasies genereer. Dit gebeur egter dikwels dat wanneer die modus van die komplementêre werkwoord verander, die semantiese implikasie (dikwels 'n fyn onderskeid) ooreenkomstig verander. Vergelyk byvoorbeeld:

32. Re fihlile bošego ra ba ba ja.

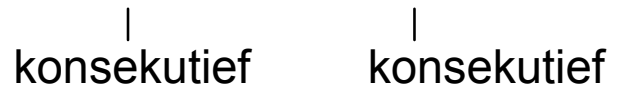

(Ons het laat gearriveer en toe uiteindelik geëet.)

33. Re fihlile bošego ya ba re a ja.

konsekutief indikatief

(Ons het laat gearriveer en daarna geëet.)

\subsubsection{Vertwyfeling/Versugting}

Hierdie betekenis word vormlik markeer deur die hulpwerkwoord met 'n onveranderlike onderwerpsmorfeem, in kombinasie met 'n komplementêre werkwoord in die indikatief en gebruik in 'n interrogatiewe konteks.

Die voorbeelde van sodanige hulpwerkwoordgroepe word in dialoogkonteks uitgelig, waar A en B twee afsonderlike sprekers aandui, byvoorbeeld:

34. A. Ke mo tseleng.

(Ek is op pad.)

B. E ba o ya kae?

(Waar gaan jy tog heen?) 
35. A. Lesogana le sentše koloi.

(Die jongman het die motor beskadig.)

B. E ba le dirile eng?

(Wat het hy tog aangevang?)

36. A. Go omile kudu.

(Dit is baie droog.)

B. E ba e tlo na neng?

(Wanneer sal dit tog reën?)

In voorbeelde 34-36 is die hulpwerkwoord en die komplementêre werkwoord skeibaar deur middel van 'n outonome woord, byvoorbeeld soos in 36(B).

E.ba pula e tlo na neng?

(Wanneer sal die reën tog val?)

Ponelis (1991:295) verwys na bogenoemde sinstipes as kleuradjunkte in vrae. Wat aspek betref, sou 'n mens Endemann (1966:50) gelyk kon gee, naamlik dat die komplementêre werkwoord in die konteks die voltooidheid of onvoltooidheid van die handeling bepaal.

\subsubsection{Intussen/Solank}

Die betekenis word in hierdie konteks vormlik gemarkeer deur die hulpwerkwoord met -ba in die indikatief, gevolg deur 'n komplementêre werkwoord in die situatief of indikatief, wat twee aksies of prosesse met mekaar in verband bring. Die hulpwerkwoord in dié konteks neem 'n veranderlike onderwerpsmorfeem ooreenstemmend met dié van die komplementêre werkwoord. 'n Hegter verhouding tussen hulpwerkwoord en komplementêre werkwoord word in dié konteks waargeneem.

Die hulpwerkwoord en komplementêre werkwoord - in teenstelling met voorbeelde 34-36 hierbo - is byvoorbeeld nie skeibaar nie. Dit kom daarop neer dat geen outonome woord (behalwe 'n ander hulpwerkwoord) tussen die hulpwerkwoord en die komplementêre werkwoord kan fungeer nie. Die volgende voorbeelde dien ter illustrasie: 
37. Ge lebenkele le tswaletšwe bana ba tlo ba ba eya gae.

(Wanneer die winkel toe is, sal die kinders intussen huis toe gaan.)

38. Ge tate a dutše a gama dipudi re ba re a di bulela.

(Terwyl my pa nog besig is om die bokke te melk, maak ons hulle solank oop.)

Skematies word die hulpwerkwoordgroepe in voorbeelde (37) en (38) soos volg voorgestel:

4.
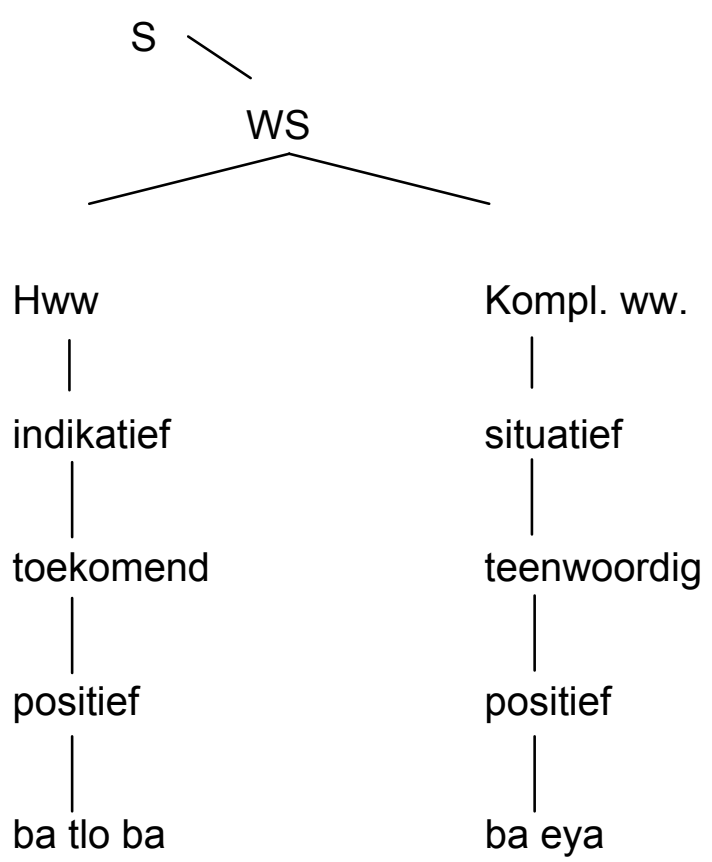
5.

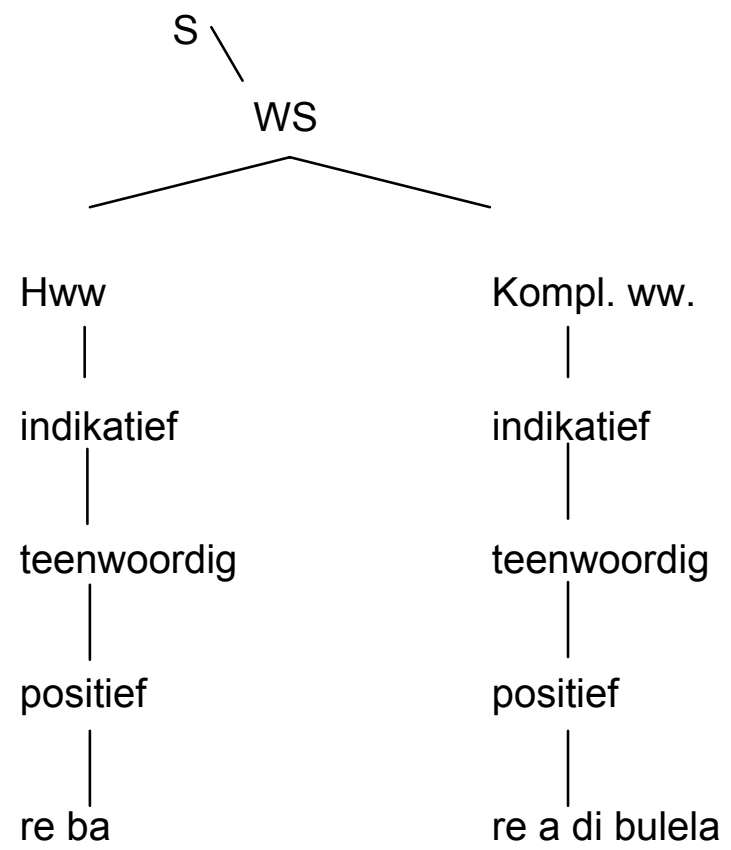

\subsubsection{Uiteindelik}

Hierdie betekenis word vormlik markeer deur die hulp- en komplementêre werkwoord, wat albei in die konsekutief voorkom. Die hulpwerkwoord in dié konteks word ook deur 'n veranderlike onderwerpsmorfeem gekenmerk, soos deur die volgende voorbeelde geïllustreer word:

39. Re fihlile bošego ra ba ra ja molatša.

(Ons het laat gearriveer en toe uiteindelik koue pap geëet.) 
6.

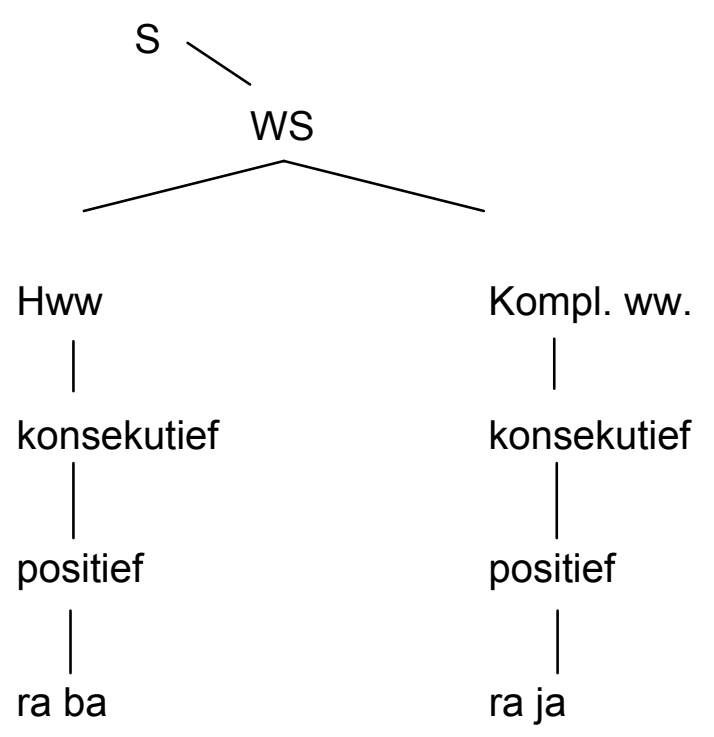

Aspektueel bepaal die komplementêre werkwoord in die konsekutief 'n voltooide handeling.

\subsubsection{Daarna (in die proses wees)}

Die betekenis word vormlik gemarkeer in kontekste waar die hulpwerkwoord met die onveranderlike onderwerpsmorfeem in die konsekutief voorkom en gevolg word deur 'n komplementêre werkwoord in die indikatief, soos deur die volgende voorbeeld geïllustreer word:

40. Re gorogile bošego ya ba re a ja.

(Ons het laat gearriveer en daarna geëet.) 
7.

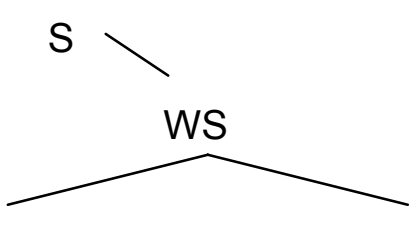

Hww

Kompl. ww.

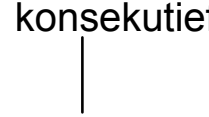

indikatief

tydloos

teenwoordig

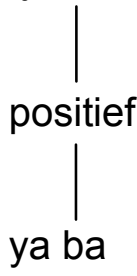

।

positief

ya ba

re a ja

Wat aspek betref, weerlê die voorbeeld hierbo Endemann (1966:50) se aanname, naamlik dat die komplementêre werkwoord die voltooidheid of onvoltooidheid van die handeling bepaal. In dié konteks is dit die hulpwerkwoord (konsekutief) wat sodanige funksie vervul. Louwrens (1994) beskou egter die konsekutief nie as 'n afsonderlike modus nie, maar 'n perfektiewe aspek van die indikatief.

\subsubsection{Vervolgens}

Hierdie betekenis word vormlik markeer in gevalle waar die hulpwerkwoord kombineer met die oorspronklike korrelaat kopulatiewe werkwoord en komplementêre werkwoord in die woordgroep. Die hulpwerkwoord neem die veranderlike onderwerpsmorfeem in dié konteks, soos deur die volgende twee voorbeelde geïllustreer word:

41. Mantšiboeng wola ba ba ba ba gona.

(Tydens daardie aand was hulle vervolgens daar gewees.)

42. Bana ba be ba bapala le dikatse ba ba ba ba le dinta.

(Die kinders was besig om met die katte te speel en vervolgens het hulle luise gekry.) 
8.

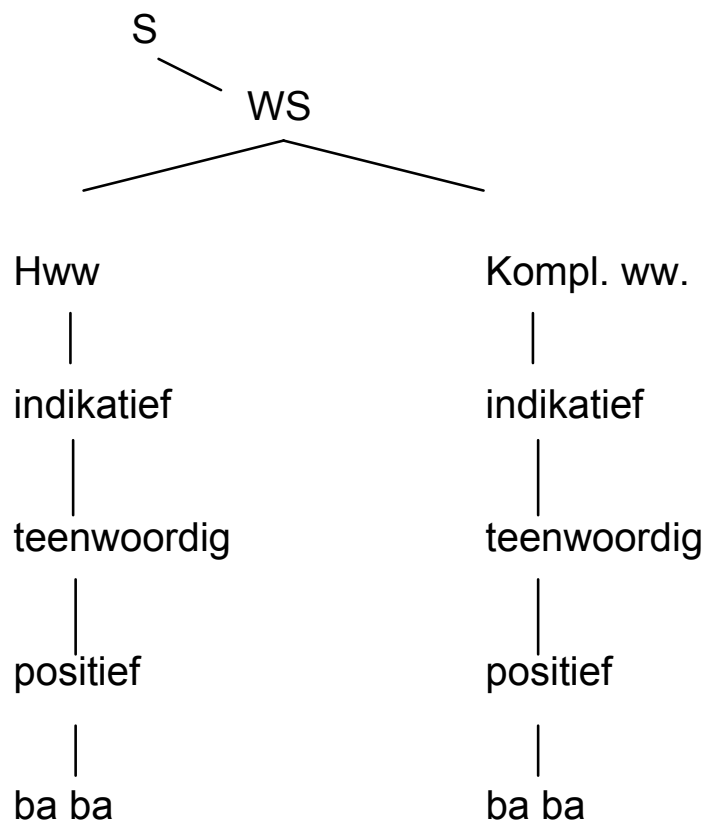

\subsubsection{Werklik/Regtig}

Die betekenis word vormlik markeer deur die hulpwerkwoord in die indikatief teenwoordige tyd (die sogenaamde lang vorm) of indikatief toekomende tyd, gevolg deur 'n komplementêre werkwoord in die situatief, soos deur die volgende twee voorbeelde geilllustreer word:

43. Rena barutiši re a ba re šoma ka maatla lehono.

(Ons onderwysers werk werklik hard vandag.)

9.

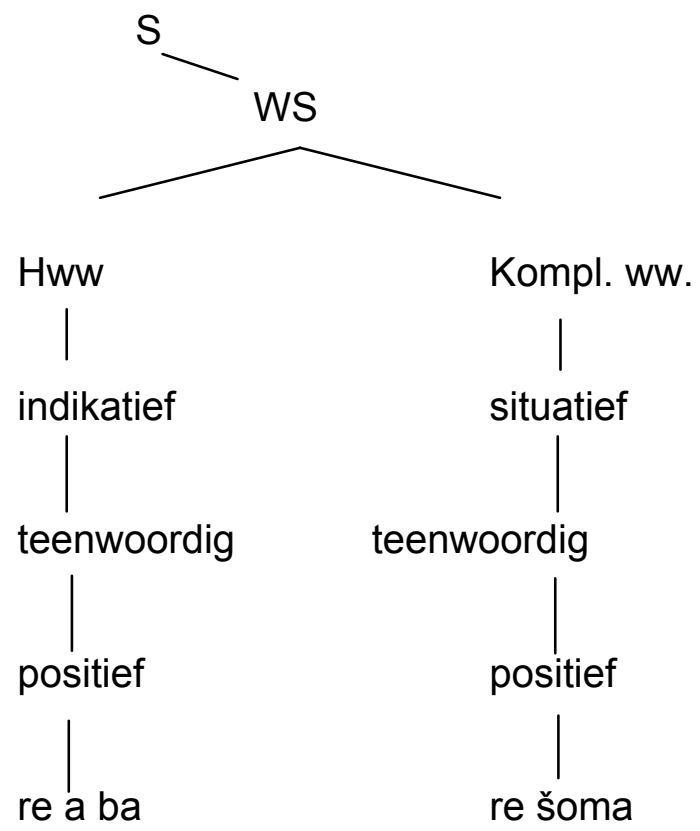


44. Ge re fihlela sekolong go tlo ba go šongwa ka maatla lehono.

(As ons by die skool aankom sal daar regtig hard gewerk word vandag.)

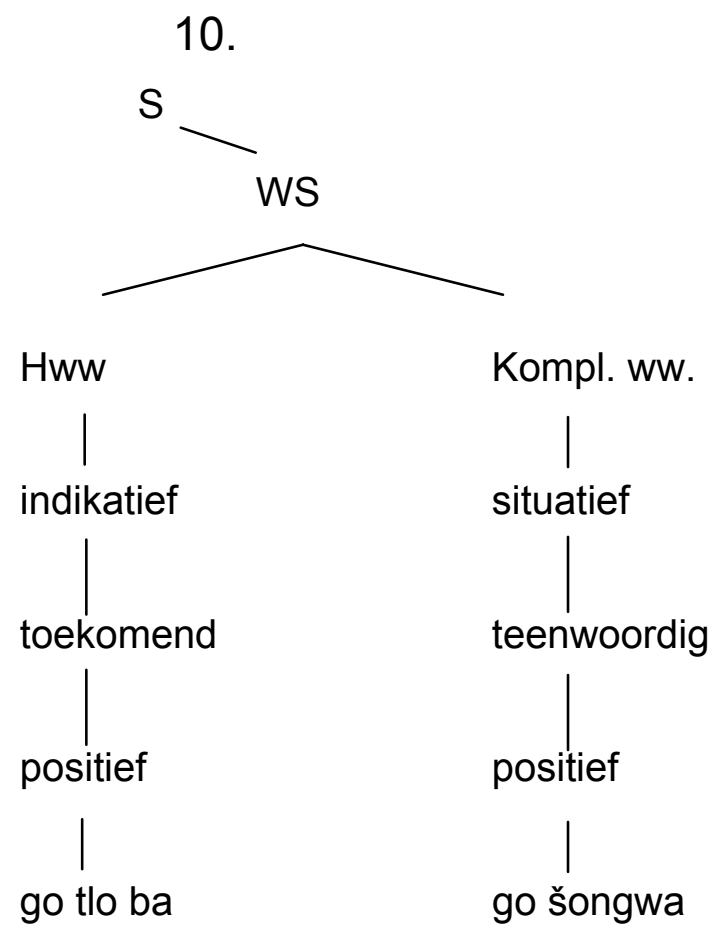

\section{Rangverskuiwing}

Soos vroeër aangetoon is, neem die hulpwerkwoordstam -ba benewens 'n veranderlike onderwerpsmorfeem - ook die onveranderlike morfeem e- met sy konsekutiewe ekwivalent ya-. In hulpwerkwoordgroepkonteks vervul bogenoemde morfeme 'n pronominale funksie. In die ontwikkelingsproses het albei hierdie morfeme, e- en ya-, hul pronominale funksies verloor en saamgesmelt met die stam -ba om 'n ander, nuwe monomorfematiese woord te vorm.

Die assimilering van die onveranderlike onderwerpsmorfeme e- en ya- (konsekutiewe) met -ba, wat in dié konteks hul pronominale funksie verloor het, lei daartoe dat dit saam met -ba 'n voegwoordelike funksie vervul. Die vorme eba/ebe of yaba/yabe funksioneer nie meer in kombinasie met 'n komplementêre werkwoord in hulpwerkwoordgroep verband nie, maar tree voegwoordelik op om twee afsonderlike sinne te verbind, byvoorbeeld: 
45. Morutiši o mo otlile gašoro yaba ngwana yoo o tšhabela nageng.

(Die onderwyser het hom wreedaardig aangerand en daarom het daardie kind die veld in gevlug.)

46. Mosadi o šomile kudu ebe a hwetša tšhelete ye ntši.

(Die vrou het hard gewerk daarom het sy toe baie geld gekry.)

\section{Gevolgtrekking}

$\mathrm{Na}$ die analise van voorbeelde 21 tot 46 , kan die volgende afleidings gemaak word:

- Die hulpwerkwoord met die stam -ba is vryer bepalend in dié sin dat die modus waarin die komplementêre werkwoord fungeer, merendeels deur semantiese oorwegings bepaal word.

- Die modus waarin die hulpwerkwoord fungeer, word ook deur semantiese faktore bepaal.

In gevalle waar die hulpwerkwoord 'n onveranderlike onderwerpsmorfeem neem, is daar ' $n$ minder hegte verhouding tussen hulp- en komplementêre werkwoord te bespeur, aangesien dié komponente in hierdie konteks skeibaar is deur middel van ander outonome woorde wat nie hulpwerkwoorde is nie.

- In gevalle waar die hulpwerkwoord 'n veranderlike onderwerpsmorfeem in ooreenstemming met die komplementêre werkwoord neem, word 'n hegte grammatiese verhouding tussen albei komponente van die woordgroep waargeneem en kan hulp- en komplementêre werkwoorde slegs deur 'n ander hulpwerkwoord van mekaar geskei word.

Die hulpwerkwoord met -ba in woordgroepkonteks word in die meeste gevalle deur die grondliggende betekenis van "in die proses wees" gekenmerk. Dit kan egter 'n verskeidenheid betekenisnuanses genereer, waarvan die Afrikaanse vertalingsekwivalente hoofsaaklik bywoordelik van aard is en wat dikwels deur ' $n$ onderliggende inchoatiewe strekking gekenmerk word.

Dit blyk in die meeste gevalle, soos Endemann (1966:50) beweer het, dat ook in dié konteks die hulpwerkwoord die tyd (tense) bepaal, terwyl die komplementêre werkwoord bepalend ten opsigte van aspek (perfektief en imperfektief) is. Uitsonderlike gevalle, waar die hulpwerkwoord in die konsekutief en die komplementêre 
werkwoord in die indikatief (vgl. voorbeeld 40) voorkom, weerlê egter Endemann se bevinding. Louwrens (1994) maak 'n sterk saak daaroor uit dat die konsekutief nie as 'n afsonderlike modus beskou behoort te word nie, maar dat dit eerder as 'n perfektiewe aspek van die indikatief geklassifiseer behoort te word.

'n Hiërargiese rangverskuiwing van die hulpwerkwoordstam na 'n monomorfematiese voegwoord vind in die ontwikkelingsproses plaas.

\section{Geraadpleegde bronne}

BEYER, G. 1920. A handbook of the Pedi-Transvaal Suto language: practical grammar with exercises, phrases, dialogues and vocabularies. Morija: Sesuto Book Depot.

ENDEMANN, K. 1876. Versuch einer Grammatik des Sotho. Berlin: s.n.

ENDEMANN, K. 1911. Wörterbuch der Sotho-sprache. Hamburg: Friedrichsen.

ENDEMANN, T.M.H. 1966. 'n Voorlopige ondersoek na aspekverskynsels in Noord-Sotho. Pretoria: Van Schaik. (Taalfasette, 2:49-60.)

HALLIDAY, M.A.K. 1961. Categories of the theory of grammar. Word, 17:92242.

KOTZÉ, A.E. 1993. Die kopulatief in Hananwa. Suid-Afrikaanse Tydskrif vir Afrikatale 13(1):16-28.

LOUWRENS, L.J. 1991. Aspects of Northern Sotho grammar. Pretoria: Via Afrika.

LOUWRENS, L.J. 1994. Aspect as an essential sub-category of the verb in Northern Sotho. South African Journal of African Languages, 14(3):116-127.

PONELIS, F.A. 1991. Afrikaanse sintaksis. Pretoria: Van Schaik.

POSTHUMUS, L.C. 1978. Die kopulatief in Zulu met verwysing na ander Bantoetale. Bloemfontein: Universiteit van die Oranje-Vrystaat. (M.A.verhandeling.)

POSTHUMUS, L.C. 2000. When does "become" become "be". South African Journal of African Languages, 20(4):342-352.

PRETORIUS, W.J. 2004. 'n Dimensionele grammatiese beskrywing van hulpwerkwoorde in Noord-Sotho. Johannesburg: Universiteit van Johannesburg. (D.Phil.-proefskrif.)

TALJARD, E. 1999. Die kopulatief van Noord-Sotho: 'n nuwe perspektief. Pretoria: Universiteit van Pretoria. (D.Litt.-proefskrif.)

VAN STADEN, W.J. 1988. Rang- en kategorieverskuiwing in Noord-Sotho met spesiale verwysing na die bywoord en die voegwoord. Johannesburg: Randse Afrikaanse Universiteit. (M.A.-verhandeling.)

VAN WYK, E.B. 1953. Die kopulatiewe van Noord-Sotho. Pretoria: Universiteit van Pretoria. (M.A.-verhandeling.)

ZIERVOGEL, D., LOMBARD, D.P., MOKGOKONG, P.C. 1969. Handboek van Noord-Sotho. Pretoria: Van Schaik. 


\section{Kernbegrippe:}

hiërargiese ontwikkeling hulpwerkwoord kategoriale verskuiwing Noord-Sotho-grammatika rangverskuiwing

werkwoordstam -ba

\section{Key concepts:}

auxiliary verb categorial shift hierarchical development Northern Sotho grammar rank shifting verb stem -ba 